Jurnal Media Pertanian Vol. 2 No. 1 Tahun 2017 Hal. 16 - 23

Media Komunikasi Hasil Penelitian dan Review Literatur Bidang Ilmu Agronomi ISSN $2503-1279$

\title{
INTENSITAS SERANGAN HAMA ULAT API (Setothosea asigna) PADA TANAMAN KELAPA SAWIT (Elaeis guineensis. JACQ) DI KECAMATAN TEBO TENGAH KABUPATEN TEBO
}

\author{
Yuza Defitri $^{1^{*}}$, Yulistiati Nengsih ${ }^{1}$ dan Harianto Saputra ${ }^{2}$ \\ ${ }^{1}$ Program Studi Agroteknologi, Fakultas Pertanian Universitas Batanghari, \\ Jl. Slamet Riyadi Jambi, 36122 Telp. +62074160103 \\ ${ }^{2}$ Alumni Program Studi Agroteknologi, Fakultas Pertanian Universitas Batanghari \\ J1. Slamet Riyadi Jambi, 36122 Telp. +62074160103 \\ *email korespondensi: yuzadefitri@yahoo.com
}

\begin{abstract}
This research aims to know the intensity of pest attacks the fire (Setothosea asigna) who attacked oil palm plants in Central Districts Tebo Tebo. This research has been carried out in the village of Mangunjayo, the village of Enclosure and the village of Tebo Tengah Sub-district Pandak Gulf County Tebo for 1 month in September 2016. Research carried out using the method of survey in the oil palm plantation folk who have produced (TM) in the village of Mangunjayo, the village of Enclosure and the village of Tebo Tengah Sub-district Pandak Bay District with an area of Tebo area $1-2$ ha. Sampling plants at each site is divided in 5 plot. Each plot was taken 5 sample plants. The observations in the field can be inferred that the intensity of the attacks the highest api pest found in Palm oil plantation in the village of Tebo Tengah Sub-district Pandak Gulf County Tebo i.e. amounting to $36 \%$. The intensity of the attack the lowest api there is a pest on Palm oil plantation in the village of Tebo Regency Central Sub Enclosure Tebo i.e. by 8\%. The difference in intensity of pest attacks also in influence by difference of height, temperature, and humidity.

Keywords: intensity of pest attacks and fire
\end{abstract}

\begin{abstract}
Abstrak
Penelitian ini bertujuan untuk mengetahui intensitas serangan hama ulat api (Setothosea asigna) yang menyerang tanaman kelapa sawit di Kecamatan Tebo Tengah Kabupaten Tebo. Penelitian ini telah dilaksanakan di Desa Kandang, Desa Mangunjayo dan Desa Teluk Pandak Kecamatan Tebo Tengah Kabupaten Tebo selama 1 bulan pada bulan September 2016. Penelitian dilakukan dengan menggunakan metode survei di lahan perkebunan kelapa sawit rakyat yang telah menghasilkan (TM) di Desa Kandang, Desa Mangunjayo dan Desa Teluk Pandak Kecamatan Tebo Tengah Kabupaten Tebo dengan luas areal $1-2$ ha. Pengambilan sampel tanaman pada setiap lokasi dibagi dalam 5 plot. Masing-masing plot diambil 5 sampel tanaman. Hasil pengamatan di lapangan dapat disimpulkan bahwa intensitas serangan hama ulat api tertinggi terdapat di Perkebunan Kelapa sawit di Desa Teluk Pandak Kecamatan Tebo Tengah Kabupaten Tebo yaitu sebesar 36\%. Intensitas serangan hama ulat api terendah terdapat di Perkebunan Kelapa sawit di Desa Kandang Kecamatan Tebo Tengah Kabupaten Tebo yaitu sebesar 8\%. Perbedaan Intensitas serangan hama juga di pengaruhi oleh perbedaan ketinggian tempat, suhu, dan kelembaban.

Kata Kunci : intensitas serangan dan hama ulat api
\end{abstract}

\section{PENDAHULUAN}

Kelapa sawit (Elaeis guineensis Jacq) adalah tanaman yang termasuk golongan palma yang merupakan penghasil minyak dan sebagai bahan baku industri makanan 
Jurnal Media Pertanian Vol. 2 No. 1 Tahun 2017 Hal. 16 - 23

Media Komunikasi Hasil Penelitian dan Review Literatur Bidang Ilmu Agronomi ISSN $2503-1279$

maupun kosmetik (Rindarkoko, 2012). Kelapa sawit sebagai tanaman penghasil minyak sawit dan inti sawit merupakan salah satu primadona tanaman perkebunan yang menjadi sumber penghasil devisa non migas bagi Indonesia. Prospek komoditi minyak kelapa sawit dalam perdagangan minyak nabati dunia telah mendorong pemerintah Indonesia memacu pengembangan areal perkebunan kelapa sawit (Hartanto, 2011).

Kelapa sawit tergolong tanaman kuat, namun demikian tanaman ini tidak luput dari serangan hama. Akibat yang ditimbulkan oleh serangan hama sangat besar, seperti penurunan produksi bahkan kematian tanaman. Hama dapat menyerang tanaman kelapa sawit mulai dari pembibitan hingga tanaman menghasilkan (Fauzi, 2006). Beberapa jenis hama penting yang menyerang tanaman kelapa sawit misalnya hama babi, tikus, kumbang tanduk, maupun hama ulat pemakan daun kelapa sawit (UPDKS) (Hakim, 2007).

Hama yang menyerang kelapa sawit pada setiap daerah tidak selalu sama. Hama tersebut ada yang bersifat permanen ada pula yang bersifat sementara. Kerugian yang ditimbulkan oleh hama sangat besar dampaknya, dapat menurunkan produksi bahkan dapat menyebabkan kematian pada tanaman. Informasi tentang hama yang menyerang kelapa sawit merupakan salah satu aspek yang perlu mendapat perhatian dalam menunjang program pengembangan pertanaman kelapa sawit, selain itu informasi tersebut juga berguna untuk mengetahui bagaimana cara pengendalian atau penanggulangan yang dapat dilakukan dengan tepat.

Berdasarkan data GAPKI pada tahun 2016, produksi kelapa sawit turun sebesar tiga persen. Total produksi minyak sawit Indonesia pada 2016 sebanyak 34,5 juta ton yang terbagi dari crude palm oil (CPO) sebanyak 31,5 juta ton dan palm kernel oil (PKO) sebanyak tiga juta ton. Sementara pada 2015, produksi CPO sebanyak 32,5 juta ton dan PKO sebanyak tiga juta ton, sehingga total produksi minyak sawit sebanyak 35,5 juta ton. Selanjutnya dijelaskan secara garis besar produksi minyak sawit pada 2016 masih relatif baik (Suryanto, 2016).

Luas areal dan produksi perkebunan kelapa sawit di Provinsi Jambi dari tahun 2014 hingga tahun 2016 mengalami kenaikan. Pada tahun 2014 luas areal 692.967 ha dengan produksi 1.777.735 ton, tahun 2015 luas areal 736.514 dengan produksi 1.947 .048 ton dan estimasi untuk tahun 2016 luas areal 757.214 dengan total produksi 2.069.879 ton (Direktorat Jenderal Perkebunan, 2016).

Berdasarkan data dari Pusat Penelitian Kelapa Sawit (2011), permasalahan penting dalam perkebunan tanaman kelapa sawit adalah serangan ulat pemakan daun yang menyerang baik pada periode tanaman belum menghasilkan (TBM) maupun tanaman menghasilkan (TM). Penurunan jumlah produksi kelapa sawit akibat serangan hama tersebut mencapai $40 \%$ atau sekitar 6,4 ton/ha.

\section{METODE PENELITIAN}

Bahan-bahan yang digunakan dalam penelitian ini antara lain tanaman sawit perkebunan rakyat yang berumur 4 tahun, alkohol 70\%, formalin $4 \%$, pinset, pita penanda pohon, spidol, kertas label, dan pensil. Peralatan yang digunakan adalah botol sampel, kotak penampung serangga, dan jaring penangkap serangga. 
Jurnal Media Pertanian Vol. 2 No. 1 Tahun 2017 Hal. 16 - 23

Media Komunikasi Hasil Penelitian dan Review Literatur Bidang Ilmu Agronomi ISSN $2503-1279$

Penelitian dilakukan dengan menggunakan metode survei di lahan perkebunan kelapa sawit rakyat telah menghasilkan (TM) di Desa Kandang, Desa Mangunjayo dan Desa Teluk Pandak Kecamatan Tebo Tengah Kabupaten Tebo dengan luas areal $1-2$ ha. Pengambilan sampel tanaman pada setiap lokasi dibagi kedalam 5 plot. Masing-masing plot diambil 5 sampel tanaman.

\section{Pelaksanaan Penelitian}

Pelaksanaan penelitian diawali dengan penentuan lokasi yang akan di survei. Penentuan lokasi didasari atas kesamaan umur tanaman yaitu 4 tahun yang terdapat di Desa Kandang, Mangun Jayo, dan Desa Teluk Pandak. Penentuan titik pengambilan sampel (sampel tanaman) dilakukan dengan menggunakan metode bujur sangkar (Pribadi, 2010). Pada setiap tanaman sampel dilakukan identifikasi terhadap jenis hama ulat api yang menyerang, jumlah/populasi hama, bagian tanaman yang diserang dan tingkat kerusakan akibat serangan.

Tanaman sawit yang terserang hama ulat api diberi tanda dengan pita penanda pohon, selanjutnya hama di ambil dengan menggunakan pinset, kemudian diawetkan dengan cara direndam kedalam botol sampel yang berisi alkohol atau formalin, selanjutnya botol sampel diberi label. Jaring penangkap serangga digunakan untuk menangkap kupukupu yang berada di sekitar tanaman sampel. Kupu-kupu yang tertangkap dikumpulkan dalam kotak penampung. Selanjutnya diawetkan dengan formalin dan disimpan di dalam botol sampel.

Parameter yang diamati adalah:

\section{Penentuan Intensitas Serangan Hama Tiap Lokasi (\%)}

Penghitungan Intensitas serangan hama dilakukan dengan menggunakan rumus oleh Tulung (2000):

$$
K=\frac{n}{N} x 100 \%
$$

Keterangan:

$\mathrm{K}=$ Persentase kerusakan tanaman pada lokasi pengamatan

$\mathrm{n}=$ Jumlah tanaman sampel yang terserang oleh hama

$\mathrm{N}=$ Jumlah total tanaman sampel dalam satu lokasi

\section{Penentuan Intensitas Serangan Hama Tiap Tanaman (\%)}

Tingkat kerusakan akibat serangan hama ditentukan dengan rumus Kilmaskossu dan Nerokouw (1993):

$$
I=\frac{n i . V i}{N . V} \times 100 \%
$$

$$
\begin{array}{ll}
\text { Keterangan; } \\
\mathrm{I} & \text { : Intensitas serangan }(\%) \\
\mathrm{ni} & \text { : Jumlah Pelepah dengan skor ke-i } \\
\mathrm{Vi} & \text { : Nilai Skor serangan } \\
\mathrm{N} & \text { : Jumlah pelepah tanaman yang diamati } \\
\mathrm{V} & \text { : Skor tertinggi }
\end{array}
$$


Jurnal Media Pertanian Vol. 2 No. 1 Tahun 2017 Hal. 16 - 23

Media Komunikasi Hasil Penelitian dan Review Literatur Bidang Ilmu Agronomi ISSN $2503-1279$

Tingkat skor yang digunakan adalah:

0 : Sehat

1 : Sangat ringan (1-20\% Pelepah rusak)

2 : Ringan (21-40\% Pelepah rusak)

3 : Sedang (41-60\% Pelepah rusak)

4 : Berat (61-80\% Pelepah rusak)

5 : Sangat berat (81-100\% Pelepah rusak).

Analisis data dilakukan secara deskriptif kuantitatif terhadap kejadian serangan dan tingkat kerusakan akibat serangan hama. Data yang diperoleh di tabulasi ke dalam bentuk tabel.

\section{HASIL DAN PEMBAHASAN}

Hasil

\section{Intensitas Serangan Hama Ulat Api Tiap Lokasi (\%)}

Berdasarkan hasil pengamatan serangan hama ulat api tiap tanaman dalam masingmasing plot, maka diperoleh data intensitas serangan hama ulat api untuk setiap lokasi yang ditampilkan pada Tabel 1.

Tabel 1 . Intensitas serangan hama ulat api tiap lokasi di Kabupaten Tebo

\begin{tabular}{|c|c|c|c|c|c|c|c|}
\hline \multirow{2}{*}{ Lokasi } & \multicolumn{5}{|c|}{ Intensitas serangan $(\%)$} & \multirow{2}{*}{ Total } & \multirow{2}{*}{ Rata-rata } \\
\hline & 1 & 2 & 3 & 4 & 5 & & \\
\hline Teluk Pandak & 60 & 40 & 40 & 20 & 20 & 180 & 36 \\
\hline Mangun Jayo & 40 & 20 & 20 & 0 & 20 & 100 & 20 \\
\hline Kandang & 0 & 0 & 0 & 20 & 20 & 40 & 8 \\
\hline
\end{tabular}

Berdasarkan Tabel 1, menunjukkan bahwa serangan hama ulat api terbanyak yang menyerang tanaman kelapa sawit untuk tiap-tiap lokasi berada pada perkebunan di Desa Teluk Pandak dengan intensitas serangan sebesar 36\%, kemudian di Desa Mangun Jayo dengan intensitas serangan sebesar $20 \%$, dan intensitas serangan hama ulat api terendah terdapat di Desa Kandang sebesar 8\%.

\section{Intensitas Serangan Hama Tiap Tanaman (\%)}

Setelah dilakukan pengamatan selama 1 bulan diperoleh data intensitas serangan hama ulat api dilokasi penelitian. Data tersebut ditampilkan pada Tabel 2.

Tabel 2. Intensitas serangan hama ulat api untuk setiap tanaman pada beberapa Lokasi di Kabupaten Tebo

\begin{tabular}{|c|c|c|c|c|c|c|c|}
\hline \multirow{2}{*}{ Lokasi } & \multicolumn{5}{|c|}{ Inensitas serangan $(\%)$} & \multirow{2}{*}{ Total } & \multirow{2}{*}{ Rerata } \\
\hline & $\mathrm{P} 1$ & $\mathrm{P} 2$ & $\mathrm{P} 3$ & $\mathrm{P} 4$ & P5 & & \\
\hline Teluk Pandak & 7.60 & 4.52 & 3.98 & 5.50 & 1.85 & 23.45 & 4.69 \\
\hline Mangun Jayo & 9.24 & 2.86 & 0.50 & 0.00 & 3.82 & 16.42 & 3.28 \\
\hline Kandang & 0.00 & 0.00 & 0.00 & 0.31 & 0.44 & 0.75 & 0.15 \\
\hline
\end{tabular}

Berdasarkan Tabel 2, menunjukkan bahwa serangan hama ulat api terbanyak yang menyerang tanaman kelapa sawit untuk setiap tanaman berada pada perkebunan di Desa Teluk Pandak dengan intensitas serangan sebesar 4,69\%, kemudian di Desa Mangun Jayo 
Jurnal Media Pertanian Vol. 2 No. 1 Tahun 2017 Hal. 16 - 23

Media Komunikasi Hasil Penelitian dan Review Literatur Bidang Ilmu Agronomi ISSN $2503-1279$

dengan intensitas serangan sebesar 3,28\%, dan intensitas serangan hama ulat api terendah terdapat di Desa Kandang sebesar 0,15\%.

\section{Gejala Serangan}

Dari hasil pengamatan dilokasi penelitian secara langsung memang tidak ditemukan ulat api, namun demikian ditemukan adanya bekas keberadaan ulat api seperti cangkang telur yang telah menetas, kepompong yang sudah ditinggalkan dan pembungkus kepompong (kokon). Untuk lebih jelasnya tanda-tanda bekas keberadaan ulat api disajikan pada Gambar 1.
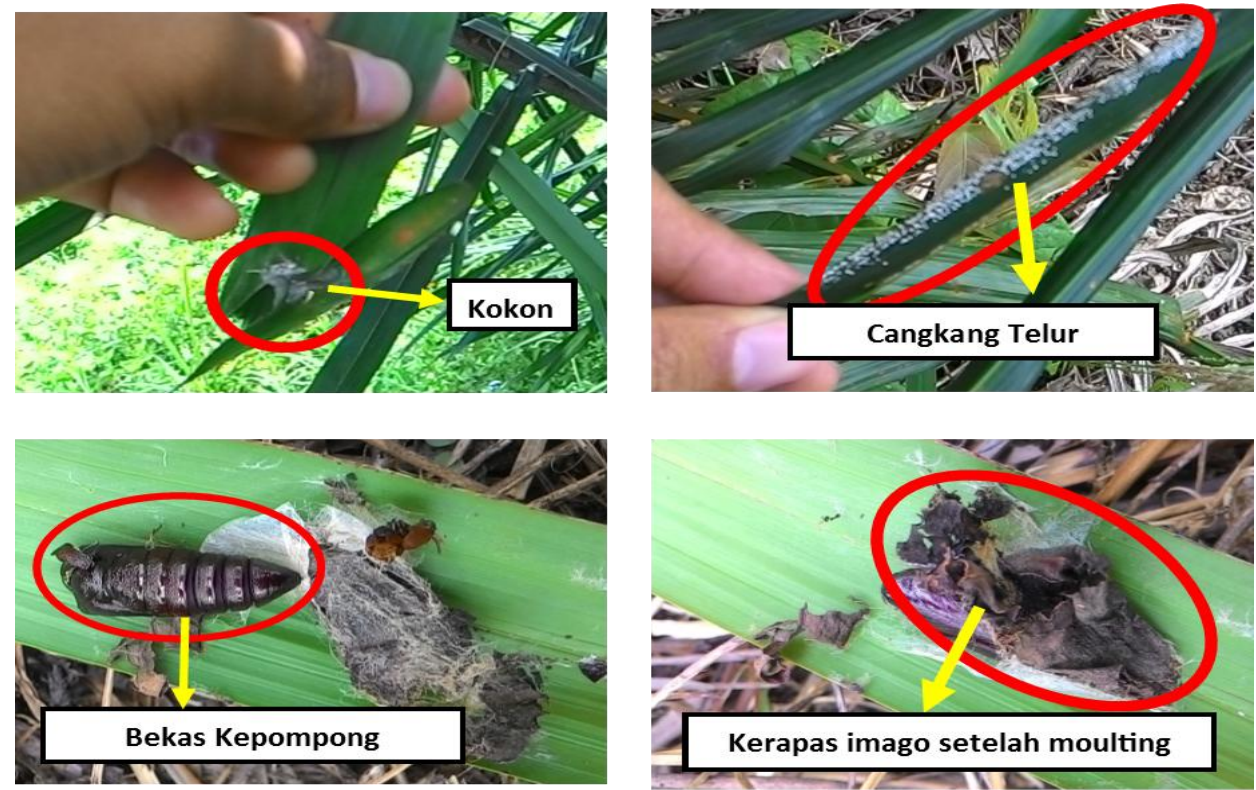

Gambar 1. Tanda-tanda bekas keberadaan ulat api

Tanda-tanda keberadaan ulat api juga ditandai dengan adanya kerusakan fisik pada tanaman kelapa sawit. Adapun ciri-ciri tersebut disajikan pada Tabel 3.

Tabel 3. Ciri-ciri fisik tanaman kelapa sawit yang terserang hama ulat api di beberapa Desa dalam Kabupaten Tebo

\begin{tabular}{|l|c|c|c|}
\hline No & Lokasi & \multicolumn{1}{|c|}{ Ciri-ciri serangan } \\
\hline 1 & Desa Teluk Pandak & $\begin{array}{l}\text { Kelai daun terkikis mulai dari } \\
\text { tepi/pinggir daun }\end{array}$ \\
$\begin{array}{l}\text { - Helai daun habis dan hanya } \\
\text { menyisakan lidi }\end{array}$
\end{tabular}


Jurnal Media Pertanian Vol. 2 No. 1 Tahun 2017 Hal. 16 - 23

Media Komunikasi Hasil Penelitian dan Review Literatur Bidang Ilmu Agronomi ISSN $2503-1279$

\begin{tabular}{|l|l|l|l|}
\hline 2 & Desa Mangun Jayo & - Helai daun berlubang memanjang \\
\hline 3 & Desa Kandang & $\begin{array}{l}\text { Helai daun terkikis mulai dari bagian } \\
\text { bawah daun hingga meninggalkan } \\
\text { epidermis bagian atas daun }\end{array}$ \\
\hline
\end{tabular}

\section{Kondisi Lingkungan}

Berdasarkan hasil pengamatan dilokasi penelitian diperoleh data mengenai kondisi lingkungan yang meliputi suhu, kelembaban, dan curah hujan. Untuk lebih jelasnya data suhu, kelembaban dan curah hujan di lokasi penelitian disajikan pada Tabel 4.

Tabel 4. Data suhu, kelembaban dan curah hujan di beberapa Desa dalam Kabupaten Tebo

\begin{tabular}{|c|l|c|c|c|}
\hline No & \multicolumn{1}{|c|}{ Lokasi } & Suhu $\left({ }^{\circ} \mathrm{C}\right)$ & Kelembaban (\%) & $\begin{array}{c}\text { Ketinggian } \\
\text { Tempat (m dpl) }\end{array}$ \\
\hline 1 & Desa Teluk Pandak & 35 & 51 & 88 \\
\hline 2 & Desa Mangun Jayo & 33 & 40 & 47 \\
\hline 3 & Desa Kandang & 38 & 33 & 39 \\
\hline
\end{tabular}

\section{Pembahasan}

Berdasarkan hasil pengamatan diperoleh data yang menunjukkan bahwa intensitas serangan hama ulat api tertinggi terjadi di Desa Teluk Pandak, kemudian Desa Mangun Jayo dan intensitas serangan terendah terjadi pada perkebunan kelapa sawit di Desa Kandang.

Tingginya intensitas serangan hama ulat api di Desa Teluk Pandak dan Desa Mangun Jayo di duga dipengaruhi oleh kondisi lingkungan. Suhu $35{ }^{\circ} \mathrm{C}$ di Desa Teluk pandak dan $33{ }^{\circ} \mathrm{C}$ di Desa Mangun Jayo merupakan suhu optimum untuk perkembangbiakan serangga ulat api. Menurut (Purba dkk, 2015) pada suhu optimum yaitu antara $25-35^{\circ} \mathrm{C}$ kemampuan serangga untuk menghasilkan keturunan besar dan kematian sebelum batas umur sedikit. Suhu berpengaruh terhadap kesuburan dan produksi telur, pertumbuhan dan penyebaran serangga.

Faktor musim juga mempengaruhi kondisi tanaman, yang mana pada saat berlangsungnya pengamatan di lapangan adalah pada akhir musim kemarau dan awal musim penghujan. Curah hujan yang cukup tinggi dengan kondisi suhu yang rendah 
Jurnal Media Pertanian Vol. 2 No. 1 Tahun 2017 Hal. 16 - 23

Media Komunikasi Hasil Penelitian dan Review Literatur Bidang Ilmu Agronomi ISSN $2503-1279$

cenderung akan meningkatkan kelembaban udara. Dari tiga lokasi pengamatan, kelembaban udara di Desa Teluk pandak (40\%) dan Desa Mangun Jayo (51\%) lebih tinggi dibandingkan dengan Desa Kandang yaitu sebesar 33\%. Tingginya kelembaban udara di Desa Teluk pandak dan Desa Mangun Jayo berdampak terhadap perkembangbiakan serangga ulat api. Kelembaban udara sangat berpengaruh terhadap kondisi perkawinan dan penetasan telur serangga (Purba dkk, 2005). Pada kondisi lingkungan dengan kelembaban yang rendah dapat menghambat perkembangan serangga hama karena berpengaruh negatif terhadap metabolisme serangga (Pribadi, 2010). Selain itu minimnya pasokan nutrisi dan air diduga menyebabkan menurunnya daya tahan tanaman terhadap serangan hama dan penyakit. Menurut Pribadi (2010), kekurangan nutrisi dan air saat musim kemarau dapat menurunkan ketahanan tanaman terhadap serangan hama. Serangan ulat pemakan daun terjadi apabila tanaman sedang mengalami stres sebagai akibat dari rendahnya nutrisi.

Dari ketiga lokasi pengamatan, Desa Kandang memiliki intensitas serangan hama ulat api terendah yaitu sebesar $8 \%$. Selain faktor lingkungan yaitu suhu dan kelembaban, rendahnya intensitas serangan diduga dipengaruhi oleh ketinggian tempat. Menurut Sudharto dkk (2005), stadium ulat lamanya 5-6 minggu pada ketinggian di atas $1700 \mathrm{~m}$, namun hanya 26 hari pada ketinggian $400 \mathrm{~m}$ dpl. Artinya semakin rendah ketinggian tempat maka semakin singkat umur ulat, dan sebaliknya semakin tinggi ketinggian tempat maka akan semakin lama umur ulat.

Data pada Tabel 4 menunjukkan bahwa dari tiga lokasi penelitian ketinggian tempat tertinggi yaitu di Desa Teluk pandak yaitu $88 \mathrm{~m}$ dpl, desa Mangun Jayo $47 \mathrm{~m}$ dpl dan Desa Kandang $39 \mathrm{~m}$ dpl. Berdasarkan hal tersebut dapat dikatakan bahwa rendahnya intensitas serangan hama di desa Kandang didukung oleh ketinggian tempat yang lebih rendah dari Desa Teluk Pandak dan Desa Mangun Jayo. Selain itu rendahnya serangan hama ulat api di Desa Kandang karena adanya kegiatan pengendalian secara kimiawi sehingga intensitas serangan hama ulat api lebih rendah dari kedua desa tersebut dan faktor lingkungan yang sangat baik ketersediaan air mencukupi karena berada di dekat aliran sungai Batanghari. Menurut Pribadi (2010), nutrisi dan air yang cukup untuk keutuhan tanaman akan meningkatkan daya tahan tanaman terhadap serangan hama dan penyakit.

Pada lokasi perkebunan kelapa sawit di Desa Kandang ditemukan adanya musuh alami (Predator) ulat api. Musuh alami (Predator) yang ditemukan di lokasi penelitian tepatnya di Desa Kandang yaitu Eochanthecona furcellata. Keberadaan predator ulat api ini diduga mampu membasmi ulat api sehingga perkembangbiakan ulat api menjadi terhambat. Berikut adalah jenis predator yang ditemukan di lokasi penelitian di Desa Kandang (Gambar 2).

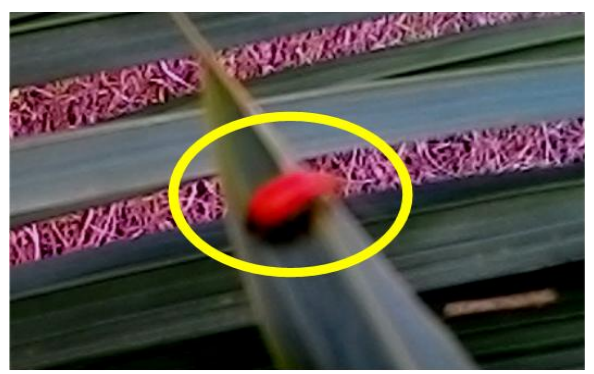

Gambar 2. Kumbang (Eochanthecona furcellata) 
Jurnal Media Pertanian Vol. 2 No. 1 Tahun 2017 Hal. 16 - 23

Media Komunikasi Hasil Penelitian dan Review Literatur Bidang Ilmu Agronomi ISSN $2503-1279$

\section{KESIMPULAN}

Hasil penelitian ini menunjukkan bahwa intensitas serangan hama ulat api tertinggi terdapat di Perkebunan Kelapa sawit di Desa Teluk Pandak Kecamatan Tebo Tengah Kabupaten Tebo yaitu sebesar 36\%, intensitas serangan hama ulat api terendah terdapat di Perkebunan Kelapa sawit di Desa Kandang Kecamatan Tebo Tengah Kabupaten Tebo yaitu sebesar 8\%. Perbedaan Intensitas serangan hama juga di pengaruhi oleh perbedaan ketinggian tempat, suhu, dan kelembaban

\section{DAFTAR PUSTAKA}

Direktorat Jenderal Perkebunan.2016. Buku Statistik Kelapa Sawit. Dirjen pertanian.go.id. 2016

Fauzi, 2006. Kelapa Sawit, Kanisius, Yokyakarta

Hakim, M., 2007. Buku Pegangan Agronomis dan Pengusaha Kelapa Sawit. Lembaga Pupuk Indonesia. Jakarta.

Hartanto, H. 2011. Sukses Besar Budidaya Kelapa Sawit. Citra Media Publishing. Yogyakarta.

Pribadi, A. 2010. Serangan Hama Dan Tingkat Kerusakan Daun Akibat Hama Defoliator Pada Tegakan Jabon (Anthocephalus cadamba Miq.) (Pest Attack and Defoliation Level on Jabon (Anthocephalus cadamba Miq.). Jurnal Penelitian Hutan dan Konservasi Alam, Vol. VII No. 4 : 451-458, 2010

Purba, R. Y. 2002. Pengenalan dan Pengendalian Penyakit Utama Pada Tanaman Kelapa Sawit. Pusat Penelitian Kelapa Sawit (PPKS). Medan, Sumatera Utara.

Pusat Penelitian Kelapa Sawit. 2011. Informasi Organisme Pengganggu Tanaman. Vol H10001. Oktober 2011.

Rindarkoko, Y. 2012. Intensitas Serangan Hama Tanaman Kelapa Sawit (Elaeis quineensis Jacq) Pada Beberapa Umur Tanaman Di Perkebunan Rakyat Desa Panggungrejo Kecamatan Panggungrejo Kabupaten Blitar. Skripsi. Jurusan Hama dan Penyakit Tumbuhan Fakultas Pertanian Universitas Jember.

Sudharto, Hutauruk P, Buana. 2005. Kajian Pengendalian Hama Terpadu $S$. asigna van Ecke (Lepidoptera: Limacodidae) pada Tanaman Kelapa Sawit. Bul. Perk. 56 (4): 103-114.

Suryanto. 2016. http://www.antaranews.com/berita/609877/produksi-minyak-sawitindonesia-turun-pada-2016. Di akses tanggal 20 April 2017

Tulung, M. 2000. Study of Cocoa Moth (Conopomorpha cramerella) Control in North Sulawesi. Eugenia 6 (4): 294-299 